\title{
Regulated selfregulation in the Netherlands, 1850-1940
}

Citation for published version (APA):

Couperus, S., \& Randeraad, N. (2014). Regulated selfregulation in the Netherlands, 1850-1940. In P. Collin, \& G. Bender (Eds.), Regulierte Selbstregulierung in der westlichen Welt des späten 19. und frühen 20. Jahrhunderts (pp. 127-147). Vittorio Klostermann. Moderne Regulierungsregime No. 4

Document status and date:

Published: 01/01/2014

Document Version:

Publisher's PDF, also known as Version of record

Document license:
Taverne

\section{Please check the document version of this publication:}

- A submitted manuscript is the version of the article upon submission and before peer-review. There can be important differences between the submitted version and the official published version of record.

People interested in the research are advised to contact the author for the final version of the publication, or visit the DOI to the publisher's website.

- The final author version and the galley proof are versions of the publication after peer review.

- The final published version features the final layout of the paper including the volume, issue and page numbers.

Link to publication

\footnotetext{
General rights rights.

- You may freely distribute the URL identifying the publication in the public portal. please follow below link for the End User Agreement:

www.umlib.nl/taverne-license

Take down policy

If you believe that this document breaches copyright please contact us at:

repository@maastrichtuniversity.nl

providing details and we will investigate your claim.
}

Copyright and moral rights for the publications made accessible in the public portal are retained by the authors and/or other copyright owners and it is a condition of accessing publications that users recognise and abide by the legal requirements associated with these

- Users may download and print one copy of any publication from the public portal for the purpose of private study or research.

- You may not further distribute the material or use it for any profit-making activity or commercial gain

If the publication is distributed under the terms of Article $25 \mathrm{fa}$ of the Dutch Copyright Act, indicated by the "Taverne" license above, 
Regulated self-regulation in the Netherlands, $1850-1940$

I Introduction

In this chapter, the notion of regulated self-regulation is examined in the context of the dynamic relationship between state and society in the Netherlands from 1850 to 1940 . During this time, the Dutch welfare state was beginning to take shape. Textbooks usually depict the construction of the Dutch welfare state as a long-drawn-out, piecemeal process, during which the state gradually took up the provision of social security. The incremental expansion of state-organized welfare, according to this narrative, mirrored the relatively slow pace of industrialization, which was lagging behind in comparison to neighboring countries. On closer inspection, however, the social state was not the outcome of a linear process predominantly characterized by increasing state intervention. By reconsidering the expansion of the welfare state, taking into account different ways of organizing social security, it is possible to advance a more nuanced interpretation of the nature and evolution of Dutch welfare. One of the main advantages of the concept of regulated self-regulation is that it allows for a broader view of welfare by dissociating it from its sometimes too narrow identification with the (central) state and including a variety of arrangements between state provision and self-help.

As the introduction to this volume asserts, different forms of regulated selfregulation exist and can co-exist. This was undisputedly the case in the Netherlands, where in the short century between 1850 and 1940, different arrangements aiming at some kind of balance between (state) regulation and selfregulation manifested themselves. This chapter looks at three configurations of regulated self-regulation, in more or less chronological order: first, the theory and practice of local government emerging from the constitutional reforms of 1848 and the subsequent Municipal Act of 1851; second, the social security system resulting from a series of acts at the beginning of the twentieth century; and third, the hybrid constellation of socio-economic arrangements at the local and central level that emerged from the outbreak of the First World War 
onwards. To be sure, these configurations do not exhaust the diversity of social security arrangements. Each of them added another dimension to state-society relations in the Netherlands, which led - as we shall argue - to a typically Dutch trajectory of welfare state formation. Although we mainly centre our analysis on legislative actions, we do not want to suggest that the initiative has always been taken by the state. Most times, the bills were a temporary pause in an ongoing negotiation between government, political parties, employers, workers, insurance companies, and other stakeholders.

II Regulated self-regulation the Dutch way:

the immanence of organicism

In order to understand the remarkable interplay between state and society in the Dutch path to welfare, we start by sketching the »administrative tradition « in the Netherlands as it began to manifest itself in the first half of the nineteenth century. Administrative tradition has been defined as »a more or less enduring pattern in the style and substance of public administration ${ }^{1}{ }^{1}$ Political scientists often use the term in order to differentiate between national traditions of public administration in large-scale comparisons. Trying to single out "variables « that impact traditions and steer path dependency, political scientists often end up with only a few, just enough to be able to keep their comparison feasible and meaningful. Without the comparative imperative, we can select our "variables more freely, and gear our sketch of the Dutch administrative tradition to finetuning the analysis of regulated self-regulation. For us, the concept of administrative tradition refers to the amalgam of ideas, practices, and perceptions with regard to public administration, which molded the Dutch state of the nineteenth and twentieth centuries, being almost invisible but omnipresent at the same time. The concept of administrative tradition helps unveil the specificities of the unified Dutch state, which all too often have been characterized as inherently peaceful and forever inclined to compromise. ${ }^{2}$

It is certainly true that toleration, accommodation, and moderation, going back to the urban-based politics of interests of the Republican regents, have deep and lasting roots in Dutch history. With the Batavian Revolution of 1795 , however, the Dutch state made a drastic turn. In the period from 1795 to 1815 ,

Martin Painter/B. GuY Peters, The Analysis of Administative Traditions, in: Martin Pannter/B. Guy Peters, Tradition and Public Administration, Basingstoke 2010, p. 6.

2 See for an overniew of the literature on the tradition of compromise Dennis Bos/Maurits Ebben/Henk te Velde (eds.), Het poldermodel van 1500 tot nu, Amsterdam 2007. the Netherlands turned into a unitary monarchy, with a strong central bureaucracy and clear hierarchical relations between centre and periphery. We intend to show that the Dutch state has since then been characterized by an ongoing tension between hierarchical control and accommodation, and between command and conciliation. This tension also underlies the »system « of regulated selfregulation we are analyzing in this contribution.

The Kingdom of the United Netherlands that came into being in 1815, when the revolutionary turmoil had come to an end, was a fusion of decentralized elements from the prerevolutionary Republic and Batavian-French innovations. In institutional terms, the latter dominated. The centralized polity, the administrative uniformization, the weakness of representative bodies, and the prerogatives of the King created a relatively strong state in comparison to the United Provinces that had gone down in the revolutionary years at the end of the eighteenth century. The strong state was embodied in the figure of King William I, who, although in name and blood represented the continuation of the old regime, was soon found to be a champion of the unitary state.

The King was surrounded by a small group of loyal officials, such as Cornelis van Maanen, who deeply believed in the "administrative monarchy" that had been installed. The new situation, however, was more generally received with mixed feelings. On the one hand, the strong executive aroused bitter resentment against governmental arbitrariness and bureaucratic centralization. Public opinion, particularly in the south, was easily stirred up against William I and his government. The air of hostility against the state galvanized the secession of Belgium in 1830 but was not confined to the South. Rather, in all parts of the country, fierce criticism of autocratic tendencies and "French excrescences" cropped up. ${ }^{3}$ On the other hand, in particular after 1830 , the growth of patriotism and religiously inspired morality brought about increasing acceptance of the state as a god-ordained principle and continued to feed antirevolutionary sentiments. The Dutch administrative tradition unfolding in the nineteenth century, in sum, proved to be an amalgamation of different and even, to some extent, contrasting elements as hierarchical control continued to compete with accommodation and passiveness, not only during the Restoration, but also atter the liberal reforms of 1848 .

The constitutional reforms brought into force by the liberal Johan Rudolf Thorbecke (1798-1872) introduced ministerial responsibility and strengthened

3 Cf. Nico RanderaAd, Ambtenaren in Nederland (1815-1915), in: Bijdragen en mededelingen betreffende de geschiedenis der Nederlanden 109 (1994: 2), pp. 209-236; JEROEN VAN ZANTEN, SChiclijk, Winzucht, Zwaarhoofd en Bedaard. 2004 
the national parliament and the representative bodies at the provincial and municipal level. However, despite Thorbecke's own rhetoric, it left the administrative framework undisturbed. Centralization, therefore, was technically largely upheld, and - as we shall see - Thorbecke knew how to use it.

It was the intrinsic threat of a revolutionary clash between state and society that drove thinkers and political leaders of radically different backgrounds together in their emphasis on the existence of organicist links between state and society. On a more theoretical level, the forced interplay of control from above and freedom of lower bodies was resolved in physical metaphors emphasizing the natural relation between the different levels. The organicism that permeated Dutch politics, however, was not an elaborate philosophical system, and in many ways less conservative than in other countries. In general, pragmatism prevailed.

This is particularly evident in the political philosophy of Thorbecke, who combined ideas from the German Historical School with principles of administrative legislation from France, Belgium, and South-German states. ${ }^{4}$ The foundation of his philosophy was a belief in an organic relationship between state and society, and between different levels of government, which meant that the two could only develop in concert. Like in the human body, where the lungs cannot exist without each other, the central and local governments depend on each other for the proper functioning of the polity. The national government asks local and provincial authorities to pursue forms of self-regulation and selfpreservation in keeping with the general laws, or in Thorbecke's own words, »in harmony with the whole.$^{5}$ In administrative practice this meant that the lower levels of government were allowed a certain amount of autonomy, but their decisions would always be verifiable by higher authorities.

Interestingly, Abraham Kuyper (1837-1920), the leader of the Protestant movement in the Netherlands and a fierce opponent of the liberals, also made use of organic metaphors to explain the nature of state and society. He developed the idea of "sphere sovereignty - the special character and independence of intermediate levels in society, such as schools, trade and industry, the family, and art. The main purpose of his theory was to keep the state from interfering in civil

4 Cf. Nico Randeraad, Thorbecke en de inrichting van het lokale bestuur, in: Tijdschrift voor geschiedenis 107 (1994: 4), pp. 537-558; NicO RANDERAad, Thorbecke en de maakbaarheid van het binnenlands bestuur, in: Bestuurswetenschappen 51 (1997: 6), pp. 344-359; JAN DRENTJE, Thorbecke revisited: de rol van het doctrinaire liberalisme in de Nederlandse politiek, in: Bijdragen en mededelingen betreffende de geschiedenis der Nederlanden 126 (2011: 4), pp. 3-28.

5 J.R. THORBECKE, Aanteekening op de grondwet, Amsterdam 1839, p. 78. society. In Kuyper's view, religious and other denominational groups were meant to organize themselves, so that the neutral state would not be able to exert its pernicious influence. The foundation in 1880 of the Free University (as in "free " from the state, although it was deeply Protestant in its academic aspirations) was one of the clearest initiatives following this line of thought. In addition, Kuyper's support for the law on Chambers of Labour (1897), which were meant to function as intermediaries between workers and employers, fits with his organic view on class relations. ${ }^{6}$

It has been convincingly argued that in their emancipatory struggle, Dutch Catholics and socialists also leaned on organicist notions. As was the case in many other countries, Catholics promoted the idea of »liberté subsidiée«, whereas early socialist leaders such as Frank van der Goes and Pieter Jelles Troelstra, going against dogmatic Marxist thought, emphasized the socialist party's need to accept and act upon the organicist development of society.

By the time labour legislation could no longer be avoided, the model of social intervention was largely a given. In order to keep the role of the state in check, political actors sought arrangements that required only financial input, but no direct control from above. In terms of regulated self-regulation, regulation here took the form of financial support although the actual implementation was meant to be self-regulated by autonomous bodies.

The historiography of the emergence of the welfare state in the Netherlands has emphasized the incremental nature of the process, characterized by a - in comparison to other West-European nations - slow development of social welfare legislation and a reluctance by the state to assume an interventionist role, resulting in a system with markedly corporatist elements. ${ }^{8}$ The highly piecemeal introduction of welfare arrangements and the sharp curb on state initiative are generally explained by the relatively late industrialization of the Netherlands, a relatively weak labour movement, the key role of confessional

6 Cf. Coen Helderman, De Kamers van Arbeid 1897-1922: een mislukte poging tot bedrijfsorganisatie, in: Tijdschrift voor sociale geschiedenis 27 (2001: 1), pp. 77-98, 126-127; ADRIEJAN VAN VeEN, The Chambers of Labour. Experiments in representation and regulation in the Netherlands in the long nineteenth century, MA thesis, Utrecht 2009 .

7 J.A.A. van Doorn, Schets van de Nederlandse politieke traditie, in: J. A. A. vaN Doors, Nederlandse democratie. Historische en sociologische waarnemingen, Amsterdam 2009, pp. 255-299, at 286-87 and 291 . 8 CF. W. ALredA/M.D. TEN HovE, Neocorporatisme: evolutie van een gedachte, P. E. VISSER, Corporatisme in Nederland: belangengroepen en democratie, Alphen aan den Rijn/Brussels 1980, Wrum CampHuYs, Tussen analyse en opporphiter de SER als advieur 
political forces (which were highly suspicious of a strong state), and the persistence of a paternalistic »old regime of social relations.

This general descriptive analysis, however, cries out for more nuanced assessments of the nature of the welfare arrangements and the role of the state. On closer inspection, the development of the welfare state was hardly a linear process and allowed for considerable differences, apparent inconsistencies, and downright contradictions. In the remainder of this chapter, we will review three settings, each showing different forms of regulated self-regulation at different levels of governance.

III Local government since 1851: Alexible regulated self-regulation

Thorbecke, the main source of inspiration for constitutional reform, also drafted the new law on local government that followed in the wake of the fundamenta changes of 1848. The parliamentary path to the new law was paved with references to contradictions between relative autonomy of local government organs (Thorbecke) and centralizing tendencies (his opponents, such as Groen van Prinsterer). For Thorbecke, organicist metaphors were helpful devices to dismiss the accusation of attempting to bring in a »French «, bureaucratic, allseeing central state. Representing the relations between state and local government as parts of one body underscored the intrinsic harmony of the polity as a functional whole.

In practice, the Dutch system of local government was not markedly different from that of many other European states, which merged Napoleonic struc tures with liberal reforms. Baden, France, Belgium, Spain, and Piedmont, for example, had preceded the Netherlands in setting up a system of administrative uniformization and centralization combined with a certain degree of municipal (and provincial) autonomy. »Bounded freedom« was the ambiguous principle that united administrative innovation in many parts of nineteenth-century Europe. In a general sense, this institutional framework can be regarded as a form of regulated self-regulation. Representative local bodies vested with power over matters of strictly local interest were paired with higher authorities at the provincial level (such as prefects, governors, and king's commissioners), who were charged with administrative oversight and auditing. To various degrees, and with marginal differences, local budgets, municipal resolutions, and local

Cf. Marcel Hoogenboom, Standenstrijd en zekerheid: een geschiedenis van oude orde en sociale zorg in Nederland, Amsterdam 2004; Chris NotTingham oude orde en sociale zorg in Nedenland, Amstedam 2004, Chrus Norn NGнам.

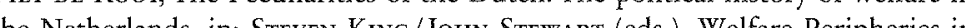

. regulations were subject to control from above. Administrative units, procedures, and competences were also, as much as possible, uniformly defined.

The differences between states were not so much in the juridical details as in the ways in which the liberal local government laws were being enforced. Geography and distance between centre and periphery, but also socio-economic conditions, political power relations, and administrative traditions hugely impacted the extent to which both local freedom and control from above were exercised. Where control was required, if only for legal reasons, public opinion tended to be more aware and critical of centralization and oppression; in contrast, if the impediments to local autonomy seemed less conspicuous, the system was regarded with greater lenience. The discrepancies also manifested themselves in markedly different historiographies with regard to local govern ment in Europe. ${ }^{10}$

The Dutch system has enjoyed relatively favourable press. In the twentieth century the term »decentralized unitary state« was coined and this concept has since become the standard mode of describing the polity. ${ }^{11}$ Despite the ideological frame, the history of Dutch local government in the second half of the nineteenth and the first part of the twentieth century shows remarkable internal differences, both between municipalities and between administrative branches. In some areas, control was rather tight (e.g. budgets and fina statements), whereas other communes could effectively resist steering from above (e. g. border changes and mergers of municipalities). ${ }^{12}$

The administrative uniformization did not prevent dramatic inequalities between larger cities and smaller municipalities in the countryside, although the law made no formal distinction between them. Whereas for the former control from above was often a mere formality, the rural villages were rigorously supervised. Throughout the nineteenth century, first the governors and later the king's commissioners (i. e. the appointed state representatives in the province) 10 Cf. Willam B. COHen, Urban government and the rise of the French city: five
municipalities in the nineteenth century, Basingstoke 1998; Nico RaNDERAaD, municipalities in the nineteenth century, Basingstoke 1998; NICO RANDERAAD, Faces of centralization: Prefers in laly and Commissioners of the King in the (ed). Medians bereen state and society Hilversu 1998, pp. 87-109; K B. (ed.), Med ha history of stake and society, Hindo 1968; As Pp. $87-109$; K. B. SMELLIE, A history of local government, London 1968, ALAN NORTON, Inter-

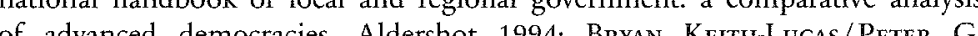
Recres A history of local government in the twentieth century London 1978. Cf. Tr. A.J. Toon Cf Nico Rande Ge Nederland, 1798-1917, Deventer 1998, pp. 246-265. 
made regular visits to the communal offices, and discussed the ins and outs of holding regular deliberations, managing finance, keeping records, and drawing up regulations with the mayors, aldermen, and other officials. Provincial capital and other bigger cities, meanwhile, were left largely undisturbed, which explains the rise of semi-autonomous expert and businesslike urban governance structures from the end of the nineteenth century onwards. Public management of water, gas, and electricity (and the revenues resulting from it) gave larger cities unprecedented opportunities to expand their municipal apparatus and carve out a bigger role for "technocrats«, who in their turn sometimes circumvented the representative organs defined by law. ${ }^{13}$

"Bounded freedom«, "decentralized unitary state«, and last but not least, "regulated self-regulation« are labels that can be (and have been) applied at will to the Dutch system of local government. It is important to note, however, that the explanatory potential of such epithets are limited. In the first case, this is because the word combinations themselves are intrinsically ambiguous, and in the second, because the administrative day-to-day reality behind the concepts showed a bewildering variety of practices. For example, if self-regulation of citie remained within the limits of the law, interference from above remained fairly restricted. On the other hand, if certain expenditures were not included in the municipal budget, higher authorities could force the local council to draw up the budget anew.

IV Social security legislation: tailor-made regulated self-regulation

Whereas local government legislation kept open a great deal of dynamism between the spheres of regulation and self-regulation, the social security legislation which entered the scene around 1900 pre-defined the domains of horizontal and vertical regulation more precisely. In this section, three legislative frameworks that provided for regulated self-regulatory practices are outlined: the Industrial Injuries Act (Ongevallenwet 1901), the Health Act (Gezondheidswet, 1902), and the Poor Law (Armenwet 1912).

In the late 1880s, following accident insurance debates in more advanced industrial states such as the German Empire, Dutch officials, politicians, trade union leaders, and employers began to contemplate a more elaborate national

13 Cf. Stefan Couperus, De machinerie van de stad: stadsbestuur als idee en praktijk, Nederland en Amsterdam 1900-1940, Amsterdam 2009; STEFAN Couperus, Backstage Politics. Municipal Directors and Technocratic Ambition in Amsterdam, 1916-1930, in: Stefan Couperus / Christianne SMIt / Dirk Jan In Control of the City: Local Elites and the Dynamics of Urban Politics, 1800-1960, Leuven 2007, pp. 175-190. system of compensation for injuries sustained at work. ${ }^{14}$ Various (industrial) accident arrangements were already in place. For example, a few cities and one important state organ, Rijkswaterstaat, which was responsible for waterways and public works, required contractors to insure their workers. ${ }^{15}$ In the $1890 \mathrm{~s}$ however, two societies for industrial accident insurance were founded in short succession. These included members from insurance companies, trade unions, and individual industrialists. Then, in 1894, the Dutch government sent two official representatives to the third International Congress of Industrial Accidents and Social Insurance held in Milan, which brought the total Dutch representation to an unprecedented six individuals. Thus, in 1897, when a more liberal government was installed, the time was ripe for the creation of a more comprehensive insurance scheme. ${ }^{16}$

Employers were the first to acknowledge the full impact of imminent nationwide social legislation. From the moment the first draft of an industrial injuries act was being circulated, employers, led by textile-industrialist Dirk W. Stork from Twente, began to organize against what they regarded as an attack on the autonomy of companies to control their own finances. They turned to the Protestant opposition leader Abraham Kuyper for support. He was more than happy to draft a fundamental amendment, preserving the compulsory character of the scheme but keeping the state at greater distance. "In the desert of the centralization the government is designing «, he proclaimed, sat least a smal private law oasis should be preserved « ${ }^{17}$ The amendment would have allowed employers to insure their workers through the Rijksverzekeringsbank, the State Insurance Bank, a newly erected state agency, or - and that was an important point for the employers - they could use their own private industrial insurance boards. Although this amendment failed, the law that was eventually passed in 1901 included the possibility of risk transfer (»opt out«) to the employers themselves, thereby securing a great deal of autonomy. On top of this, private parties could lodge an appeal against decisions made by the public Rijksverzekeringsbank.

14 CF. W. DE VRIES, De totstandkoming van de Ongevallenwet 1901: de invloed van werkgevers en werknemers op de eerste sociale verzekeringswet in Nederland, Deventer 1970; RoB J.S. SwITTERs, De risico's van de arbeid: het ontstaan van de Ongevallenwet 1901 in sociologisch perspectief, Groningen 1991.

15 Dirk Damsma/ Piet de Rooy, Morele politiek: de Radicalen in de Amsterdamse gemeentepolitiek 1888-1897, in: Tijdschrift voor sociale geschiedenis 19 (1993 ), pp. 115-128; DirK Jan WolfFram, Vrij van wat neerdrukt en beklemt. Staat, gemeenschap en sociale politiek (1870-1918), Amsterdam 2003, p. 105.

Cf. DE VRIES, De totstandkoming (n. 14)

Cited in: JACQUES VAN GERWEN, De ontluikende verzorgingsstaat: overheid, vakbonden, werkgevers, ziekenfondsen en verzekeringsmaatschappijen 1890-1945, Amsterdam 2000, p. 164. 
Even before Parliament accepted the law, the employers had clearly recognized the importance of organized lobbying. In 1899, at the same time Kuyper handed in his first amendment, the national Vereeniging van Nederlandsche Werkgevers (the Association of Dutch Employers) was founded. The Industrial Insurance Act, therefore, not only heralded the introduction of the welfare state in the Netherlands, but also helped institutionalize self-regulation in the field of social security. Shortly after the promulgation of the law, the employers founded their own insurance bank, the Centrale Werkgevers Risico-Bank (Central Employers Risk Bank), which became a powerful competitor of the state-managed Rijksverzekeringsbank. ${ }^{18}$

For municipalities, it also appeared less expensive and more efficient to bear the risk of accident insurance themselves rather than pay fixed sums to the Rijksverzekeringsbank In 1906, they founded the Onderlinge Risico-Vereeniging van Nederlandsche Gemeenten (Mutual Risk Association of Dutch Municipalities), which by 1912 grew into a more comprehensive association representing an increasing number of Dutch municipalities, the Vereeniging van Nederlandsche Gemeenten (Association of Dutch Municipalities), which was comparable to the slightly older German Städtetag. Another long-term effect, bringing in a selfregulatory element, was the inclusion of medical doctors in the institutionalization of social care. ${ }^{19}$

The Industrial Injuries Act itself was a clear attempt at centralized regulatory intervention, albeit being limited for a time to »dangerous « industries. Insurance was compulsory and costs were borne by the employers. Opt-out possibilities for employers were intended to enhance efficiency and cost-effectiveness, although ideological arguments frequently overshadowed the financial state of affairs. The Rijksverzekeringsbank became the main agency of payment, registration, and control (also of private parties). The bank was also a platform for tripartite consultation. Its supervisory board, local branches, and appeal council included representatives of workers, employers, and »independent« state officials. As in-

18 Cf. Peter KerRLAan, De lange houdbaarheid van de ongevallenwet in Nederland 1901-1967, in: Tijdschrift voor sociale en economische geschiedenis 3 (2006: 4), pp. 64-90; LOES VAN DeR VALK, Private or public? The Dutch debate about social insurance statistics (1900-1940), in: PauL S.M.M. KLep/Jacques G. S.J. vaN Maarseveen/IDa H. Stamhuis (eds.), The statistical mind in modern society: The Netherlands 1850-1940, Amsterdam 2008, pp. 289-311; LOES VAN DER VALK, Taak, bevoegdheid en prestaties van "risico-overdracht« onder de Nederlandse ongevallenwet 1901, in: Tijdschritt voor sociale en economische geschiedenis 7 (2010: 4), pp. 50-74.

19 Cf. D. RigTer, Het effect van de invoering van de Ongevallenwet 1901 op de gezondheidszorg, in: K.P. CoMPANJE (ed.), Tussen volksverzekering en vrije markt: verzekering van zorg op het snijvlak van sociale verzekering en gezondheidszorg 1880-2006, Amsterdam 2008, pp. 97-172. surance bank, however, the Rijksverzekeringrbank was not very successful, at least in its early years. Competition from private parties proved to be fierce and resulted in considerable deficits. As a regulatory agency, however, the Rijksverzekeringsbank was a forerunner of corporatist arrangements. These became char acteristic of welfare organization in the Netherlands, first in a piecemeal fashion atter the First World War, and then serving as a standard point of departure for consultation between stakeholders after 1945

The regulated self-regulatory practices resulting from the Industrial Injuries Act shows how social legislation relating to labour became organized in a hybrid structure encompassing public and private agencies. Another significant law, the Gezondsheidswet of 1902 (Health Act), discloses a somewhat different pattern of self-regulation. Up until the promulgation of the Health Act, the regulation of public health was a matter for local governments. The Municipal Act of 1851 and additional legislation concerning medical supervision promulgated in 1865 assigned municipalities with the task to regulate public health. Various (mainly urban) municipalities installed health boards, comprising local notables and medical doctors. The health boards were primarily involved in researching hygienic conditions and epidemic diseases. ${ }^{20}$ In 1893, Amsterdam was the first city to create a municipal health agency (Gemeentelijke Gezondheidsdienst) that actually implemented street level action by local officials. Private initiatives to ameliorate public health were proliferating as well.

In 1902, as part of increasing centralized regulation and closer inspection of public health, local health commissions became mandatory for all municipalities with over 18,000 inhabitants. The work of the local health commissions was intimately linked to the Woningwet of 1901 (Housing Act), which allowed municipalities - after compulsory advice by the health commission - to close down uninhabitable dwellings. The central state did not take the overarching tasks of control and supervision in its own hands but instead installed a supreme board of experts, the Centrale Gezondheidsraad (Central Health Council), which nominated the members of local health boards and operated independently of the government. ${ }^{21}$ As such, the state delegated the supervision and central steering of local public health regulation to a body of (male) experts, and, at the same time, endowed the body with advisory capacities. After two decades of mixed results and discord among its members, the state deprived the Central Health Commission of its regulatory and supervisory powers. From 1920 onwards, the new Health Commission continued its work solely as a govern-

20 E. S. Houwaart, De Hygiënisten. Artsen, staat \& volksgezondheid in Nederland 1840-1890, Groningen 1991, p. 375

1 R. B.M. Riche Ge 1902-1985, Rotterdam 1992, pp. 47-71. 
mental advisory body comprising experts and interest group representatives. This lasted until 1933, when the local health commissions were abolished as part of cutback policies and the Ministry of Health began to intervene directly in the local self-regulation of public health.

In sum, for many years, the regulation of public health was organized locally. However, the experiment failed to combine the self-regulatory capacities of the municipal health commissions (many of which originated in the mid-nineteenth century), with a supervisory and controlling central expert body. Consequently, the central state ultimately encroached on local affairs, resulting in the abolishment of self-regulatory practices during the economic crisis of the 1930s, when local bodies could no longer be financially sustained.

The third legislative setting, which illustrates another variant of regulated selfregulation in the field of social security arrangements, relates to poor relief. Traditionally, poor relief in the Netherlands was under the remit of the churches. State intervention aimed first and foremost to keep it that way. The Poor Law of 1854 thus decreed that only in cases of »absolute inevitability" were state authorities (usually local government) allowed to offer relief. Despite increasing pressure from progressive liberals and socialists, the new Poor Law of 1912 made few structural changes. The first responsibility for poor relief continued to lie with religious and private institutions. As an authoritative historian in this field stated, the law stood with its back to the future. ${ }^{22}$ One innovation, however, was the establishment in bigger cities of armenraden, councils for poor relief, which, on a voluntary basis, united all local institutions dealing with support to the poor.

This organizational novelty was rooted in earlier attempts at regulation. Since the end of the nineteenth century, charitable institutions in the Netherlands had initiated projects to reach higher levels of cooperation and self-regulation. In 1898, poor relief institutions in Amsterdam gathered in a local Vereeniging van Armbesturen and in 1908, the Nederlandsche Vereeniging voor Armenzorg en Weldadigheid was founded. These examples set the stage for the new Poor Law. Both state regulation and self-regulation of poor relief institutions, however, were difficult to achieve in a field which was so fragmented. Bigger cities often had dozens of organizations dealing with poor relief. Regulation collided with the self-interest and secrecy of local institutions, which were frequently reluctant to share information with the councils, where they existed, or with local government. Thus, to some extent, in contrast with the earlier examples, the

22 Marco H. D. van Leeuwen, Armenzorg 1912-1965: van centrum naar periferie, in: Jacques van Gerwen / Marco H. D. van Leeuwwen (eds.), Studies over zekerheidsarrangementen: risico's, risicobestrijding en verzekeringen in Nederland vanaf de Middeleeuwen, Amsterdam 1998, pp. 520-569, 521. regulation of poor relief remained at fairly low levels, even after the new Poor Law of 1912, which brought little innovation.

The illustrations above relating to social security legislation show differen arrangements of regulated self-regulatory practices. The three areas of socia security (labor accidents, public health, and poor relief), show how, in divergent configurations, different governance arrangements and a wide variety of actors engaged in practices in regulated self-regulation. Attempts to centralize (i. e. public health) or de-privatize (i. e. poor relief) regulatory arrangements failed to a great extent because it proved difficult to change existing practices. All in all, it could still be maintained that regulated self-regulation was the main mode of regulatory practice, although no single blueprint existed for the organization of the proliferating social security schemes.

V Hybridity, centralization, and fragmentation: regulated self-regulation during the interwar period

The third configuration of Dutch regulated self-regulation roughly spans the interwar years. During this period, the existence of a wide variety of regulated self-regulatory practices characterized the socio-economic domain of governance and policy-making. The delegation of regulatory tasks to a nexus of intermediary institutions accelerated significantly. Corporatism, broadly understood as collaborative structures of interest conciliation sanctioned by the state, was widely perceived of as a »problem-solving « mechanism in the regulation of society at large. ${ }^{23}$ The proliferation of this nexus can be related to a perceived double deficit, which gained prominence during the First World War. First, the capacity of the social state to oversee and steer the expanding range of interventionist politics was insufficient. The delegation of certain activities (i. e. regulatory tasks) was imperative to the solution of this functional deficit, as was the expansion of the administrative apparatus. Second, the range of socio-economic policies on which the central state was embarking, initially with regard the wartime scarcities (e.g. unemployment, food distribution, and housing shortages), needed more extra-parliamentary support in order to obtain a certain degree of legitimacy and efficacy. Nationally organized interest groups were increasingly incorporated into the organization of welfare arrangements to foster societal consent. Consequently, the state increasingly allowed for the substitution of state regulation with modes of regulated self-regulation: it began to focus on the limits and demarcations of extra-parliamentary governance clusters or formalized networks instead of enhancing an exclusive focus on direct steering

23 Frans van Waarden, Corporatisme als probleemoplossing, in: Verhallen, Corporatisme in Nederland (n. 8), pp. 17-69. 
mechanisms. ${ }^{24}$ In other words, controlled self-regulation and co-regulation became the main regulatory instrument.

By the end of the First World War, the chart of public-private collaborations aimed at managing crises and welfare arrangements was mounting in the Netherlands. Hubs in which interest groups, state officials, and/or experts were combined, either state-initiated or created by voluntary associations from the bottom-up, were vested with a variety of tasks ranging from supervision to policy execution, from arbitration to consultation, and from interest conciliation to modes of self-regulation. In the field of housing and employment, national councils were established in which interest groups, local and national officials, and professional associations deliberated about topical (e. g. rents and employment mediation) and structural (e.g. housing shortages and rising unemployment) issues. ${ }^{25}$ From within the ranks of the Royal National Committee for Support (Koninklijk Nationaal Steun-Comitê), which was founded to provide for public-private partnerships to tackle the wartime crisis, the ad-hoc convention of industrial employers and their associations resulted in the foundation of the Industrial Council (Nijverheidsraad) in $1919 .{ }^{26}$ In a similar vein, the self employed organized themselves in a Council for the Self-Employed (Middenstandsraad) that same year. ${ }^{27}$ Both councils were sanctioned - and sponsored - by the government as their official consultants in matters related to industry and small businesses. ${ }^{28}$

The government itself founded the Commission for Economic Politics (Commissie voor de Economische Politiek) in 1917. ${ }^{29}$ This commission epitomized

24 Andrew Barry/Thomas Osborne/Nikolas Rose, Foucault and Political ReaANDREW BARRY/THOMAS OSBORNE/NIKOLAS ROSE, Foucault and Political Rea-
son: Liberalism, Neo-Liberalism, and Rationalities of Government, Chicago son: Libera
1996, p. 8.

25 C.. B. G.A. Kempen/N. van Velzen, Werken aan wonen: 75 jaar Nationale C. B. G.A. KEMPEN/N. VAN VELZEN, Werken aan wonen: 75 jaar Nationale
Woningraad, Almere 1988; P. DE Roor, Werklozenzorg en werkloosheidsbestrijding 1917-1940, Amsterdam 1979.

26 Cf. Ivo KuYPERS, In de schaduw van de grote oorlog: de Nederlandse arbeidersbeweging en de overheid, 1914-1920, Amsterdam 2002; S. F. KRUIZINGA, Economische politiek: de Nederlandsche Overzee Trustmaatschappij (19141919) de CAMMNa, Ondenters verbond 100 jar cer

27 Cf. P. A. van den Dungen, De middenstandsbeweging in Nederland, Tilburg

28 P. E. DE HEN, Actieve en re-actieve industriepolitiek in Nederland: de overheid en de ontwikkeling van de Nederlandse industrie in de jaren dertig en tussen 1945 J. A. Nomsterdam 1980, pp. 23-33.

29 J.A. Nerkers / W. H. SAlzManN, Een wheilzaam orgaan in ons staatsleven«? De Economische Raad als deskundigencollege 1932-1938, in: Economisch- en sociaal-historisch jaarboek 53 (1990), pp. 191-224. the belief in involving interest groups in the governance and regulation of the national political economy. A mix of trade union and employer representatives, economic experts, ministers, and state officials replaced the existing »old boys network of (retired) entrepreneurs and bankers to act as the government's pool of advisors during the adaptation to the new post-Versailles economic order. Installed by the liberal prime-minister Cort van der Linden, it was hailed as »a supreme economic council«, a vehicle to secure the input of expertise and science into government as well as a means to secure interest representation in socio-economic regulation. Two years later, the Catholic minister of economic affairs P.J. Aalberse set up the High Council of Labour (Hooge Raad van Arbeid). ${ }^{30}$ The High Council was designed as a tripartite (employers, workers, and experts) organ which, primarily, was meant to advise the government on social policies, but also served as a conciliatory forum for capital and labour. ${ }^{31}$

In short, by the late 1920s, a number of national councils had been put into place, constituting a complex structure of institutions with varying degrees of functional representativeness and proximity to the government and its agencies. $^{32}$ They were either public councils, sanctioned by government through Royal Decree, or private organs of aggregated interests (e.g. in the field of horticulture or housing), which de facto turned out to be consultants to the government. Although mainly defined as advisory organs to the government and its agencies, as part of what the French literature calls "l'administration consultative", most of these national councils gradually employed additional selfregulatory tasks. ${ }^{33}$

Initially, it was the perceived "self « that provoked debate about the demarcation of the professional group or economic branch that was to be regulated. During the 1920s, the question of self-regulation was mainly about who or what was to be regulated, and how to aggregate partial interests, rather than what the scope and substance of self-regulatory activity had to be and to what extent the state could legitimately determine the scope of self-regulatory activity. ${ }^{34}$ In other words, the primary question was who belonged to the functional demos that was entitled to be represented in extra-parliamentary councils, which, in turn, would exert what kind of regulatory powers?

30 Coen Helderman, De Hoge Raad van Arbeid, 1919-1940(-1950), in: Tijdschrif voor sociale en economische geschiedenis 1 (2004: 2), pp. 45-70

Cf. A. W. Ouint, Twintig jaar Hooge Raad van Arbeid, Haarlem 1940.

32 PAUL DEN HOFD/ANNE-GREeT KIZER Op steenworp afstand: op de brug tussen PAUL DEN HOED/ANNE-GREET KEIZER, Op steenworp afstand: op de brug tussen

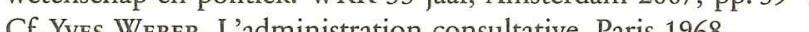

34 STEFAN Couperus, Fixing Democracy? Political Representation and the Crisis of Democracy in Interwar Europe and the Netherlands, in: JoRIS GIJSENBERGH et al. (eds.), Creative Crises of Democracy, Brussels 2012, pp. 269-290. 
The very existence of these advisory and self-regulatory bodies ignited an even more principled debate about the extent to which their regulatory and advisory powers equated - or would equate - legislative or decreeing capacities. The constitutional reform of 1922 vested the debate with urgency. Key to this reform was the adoption of a constitutional article that theoretically enabled the creation of legislative public organs, other than the national, provincial, and local parliaments, and the odd figure of the elected water boards responsible for water management. A parliamentary majority supported the socialist leader P.J. Troelstra who urged for the mandatory inclusion of the same advisory councils in public law, which did not necessarily entail the adjudication of legislative powers. The lack of a legal framework defining the composition, tasks, and procedures of these bodies made them uncontrollable by the highes legislative authority: the national parliament. Troelstra thought the parliament should have a say in the definition of these intermediary organs and not leave their activities to the mere caprices of organized interests or ministers. Pu differently, the adjective »regulated « had to be prefixed to self-regulation by means of defining the legal options and limits for each of these organs. ${ }^{35}$ The process of enactment, from 1922 onwards, proved troublesome and laborious. Only the High Council of Labour (1927), and the newly established Economic Council (1932), were defined by specific laws. Other councils maintained a great deal of autonomy in defining their composition, regulatory tasks, and working procedures.

The new elements of the constitution tapped into an ongoing ideological debate about the way in which the Dutch polity had to be organized, which to some extent revived organicist theories, albeit with a remarkable twist. Harkening back to the late-nineteenth-century discussion about the re-corporatisation of society and its indebtedness to the medieval and early modern guilds, sociopolitical theorists and politicians not only debated the theoretical assumptions underpinning state-society relations, but also, more practically, how existing practices of self-regulation could support an alternative politico-administrative structure alongside or as a substitute to parliamentary democracy.

One of the most prominent Catholic advocates of organicist self-organisation and self-regulation, J.A. Veraart, initiated a private scheme, which from 1919 onwards was meant to operate within Catholic circles. ${ }^{36}$ The so-called Bedrijfsverenigingen were envisaged as self-regulatory institutions, in which (Catholic)

35 Den Hoed/Keizer, Op steenworp (n. 32), pp. 57-59.

W. G. J. M. ToMASSEN, Het R.-K. Bedrijfsradenstelsel (1919-1922): de eerste poging tot publickrechtelijke bedijifsorganisalie op organischsolidaistische grondslag binnen de moderne industrële samenleving in Nederthond, Leiden 1974. employers and workers would collaboratively regulate working conditions, social insurances, and wages. However, due to reluctance among the Catholic employers, the experiment failed within two years. ${ }^{37}$

Within confessionals circles, proponents of a corporatist polity put forward models of an organic unity of state and society, made up of functionally defined socio-economic groups. ${ }^{38}$ Orthodox-Protestants promoted the gradual bottomup evolution of social organicism, whereas convinced Catholic corporatists wanted the state to catalyze the process of social organisation. ${ }^{39}$ Socialists proposed to integrate existing advisory bodies into new arrangements, which would bring forth state-controlled participation of societal interests (i. e. mainly workers) in social policy-making. ${ }^{40}$ In other words, they favoured a mode of regulated self-regulation, allowing state-sanctioned public bodies to obtain decreeing powers within a particular domain of action. This notion of statutory industrial organisation (publiekrechtelijke bedrijfsorganisatie) represents the core of the Dutch conception of regulated self-regulation during the interwar period.

The statutory organisation of the economy revolved around one key theme: the establishment of a legislative framework that would provide for public, multipartite institutions as the main vehicles for the regulation of each private subsector in the national economy. Although such a full-fledged system did not take shape before the late 1940s, the contested Bedriffsradenwet (Joint Industria Councils Act) of 1933 enabled the creation of a series of decentralised representative bodies with equal representation of employers and workers to which advisory and regulatory tasks regarding wage bargaining and the determination of working conditions within a certain industry were assigned. These councils

37 Mirjam Hertogh, "Geene wet, maar de Heer!« De confessionele ordenin van het Nederlandse sociale zekerheidsstelsel (1870-1975), The Hague 1998, pp. $168-169$.

38 Anton Hemerijck, The Netherlands in Historical Perspective: The Rise and Fall of Dutch Policy Concertation, in: Stefan Berger/Hugh Compston (eds.), Policy Concertation and Social Partnership in Western Europe. Lessons for the 21st Century, New York/Oxford 2002, pp. 221-233, 225-227.

39 J. Bosmans, Romme: biografie 1896-1946, Utrecht 1991, pp. 243-255; H. DE Liagre BöHL, De confessionelen en het corporatisme in Nederland, in: PAut LuYkX/Hans Righart(eds.), Van de pastorie naar het torentie. Een eeuw confessionele politiek, The Hague 1991, pp. 104-123, 104-106; vgl. G.J. M. VAN WISSEN, De christen-democratische visie op de rol van de staat in het sociaaleconomisch leven, Amsterdam 1982, pp. 37-47, 111-123, 150-151.

40 Peter Jan Knegtmans, Socialisme en democratie. De SDAP tussen klasse en natie (1929-1939), Amsterdam 1989, pp. 145-151; ERNEST Hueting/Frits DE Jong Edz./Roв NeIJ, Troelstra en het model van de nieuwe staat, Assen 1980, pp. 102-111. 
(Bedrijfsraden) stood midway between the compulsory German Betriebsräte, which operated on the work floor level, and the voluntary British Whitley Councils, which covered a whole industry. ${ }^{41}$

Despite the shift from decentralised to centralised institutions that occurred during the interwar period, one has to take into account that various decentralised regulated self-regulatory practices continued to exist or came into being. Though fundamentally reformed in 1920, the regional Chambers of Commerce (Kamers van Koophandel en Fabrieken), for instance, were able to generate their own financial means by managing the trade register (every member had to pay a certain fee), which, in turn, resulted in a myriad of self-financed activities to promote regional trade and industry during the 1920 s and 1930 s. $^{42}$ Educational courses, incentive policies, consultancy agencies and network activities became part of an economic program largely independent from state interference.

Furthermore, in 1919, 39 decentralized bipartite Councils of Labor (Raden van Arbeid) were installed, which added to the hybrid system that regulated, managed, and administered social insurances such as invalidity benefits, pensions, and accidents, sickness, and child allowances. The Rijksverzekeringsbank and privately established business associations, some of them united in the Centrale Werkgevers Risico-Bank, were also entitled to implement and manage (part) of these insurances. ${ }^{43}$

Within the realm of urban governance, various local authorities set up new deliberative, self-regulatory platforms, coordinated by the municipalities themselves. During the First World War, cities such as The Hague, Amsterdam, and Rotterdam had adopted general wage bargaining schemes, which allowed in trade unions of municipal personnel. So-called »contact commissions « provided for deliberation between representatives of local interest groups and municipa agencies, particularly in the field of retailing and housing. By the 1930s, some cities (such as Amsterdam and Nijmegen) founded deliberative bodies in which the most important interest groups and voluntary organizations would have a say on socio-economic affairs. In the case of Amsterdam, agreements reached by the Food Council (Levensmiddelenraad) directly related to certain municipa regulations regarding the opening hours of shops and the introduction of a licensing system. De facto, therefore, the regulation of the local economy was delegated from the town hall and its agencies, to a council of public and private

41 Antorne T.J.M. Jacobs, Labour Law in the Netherlands, The Hague 2004, p. 135 .

42 J.M. M. J. CleRX, De Kamers van Koophandel en Fabrieken. Van slaapkamers via rustkamers naar werkkamers, in: Politiek(e) Opstellen 7 (1987), pp. 63-74, 65. 43 Cf. P. L. GerRITSE, Van arbeid en groei: uit de geschiedenis van de Vereeniging van Raden van Arbeid: 1920-1940, Amsterdam 1940. stakeholders. ${ }^{44}$ As such, local practices of regulated self-regulation, taken to gether, shaped a new realm of (local) state-society relations, which enabled municipalities to employ new administrative activities despite the increasing weight of the central state, particularly in municipal finances. Put differently, since 1851 municipal governance had evolved as the expression of an organicis conception of regulated self-regulation (the »decentralized unitary state «), whereas from the late 1920s onwards, local authorities increasingly marked the limits of local self-regulatory practices themselves.

The outbreak of the Second World War, and the swift occupation of the Netherlands by the Nazis, ushered in a period during which the existing configurations were substituted by Berlin-approved institutional hierarchies. Existing organised interests were subjected to the tactics of German Gleichschaltung and the hybrid and multiform complex of regulatory arrangements were subsumed under strictly ordered centralised systems, of which the Woltersom Committee for Industrial Organisation is one of the best-known examples. ${ }^{45}$

\section{Conclusion}

We have tried to show that the practices of regulated self-regulation that emerged over the ninety years between 1850 and 1940 have deep roots in a Dutch administrative tradition characterized by a lasting tension between control and accommodation. The emergence of the social state reinforced the remarkable interaction of these two types of regulation. To put it differently regulated self-regulation as it evolved in the Netherlands combined the deepseated and often cited »symbiotic relationship between state and private initiative with the ingrained confessional aversion to state-controlled governance. ${ }^{46}$ From the end of the nineteenth century onwards, numerous hybrid structures that balanced these tendencies were devised at various levels of governance and within various domains of society. Although during the first wave of social legislation in the early 1900s, centralization and state control began to emerge as a clear tendency, the actual regulatory practices, in mos cases, were kept at a distance from direct state interference. The government

44 Stefan Couperus, Parcelling out municipal administration and power in Amsterdam, 1880-1940, in: The International Journal of Regional and Local Studies. Series 2, 7 (2012: 1/2), pp. 65-89, 77-83.

45 Jan NerKERs, Tussen staatssocialisme en vrije markt: ontwikkeling en functioneren van de Organisatie-Woltersom en de Organisatie voor de Voedselvoorziening als intermediaire organisaties tussen overheid en bedrijfsleven in Nederland tijdens de Tweede Wereldoorlog, Leiden 1987.

46 Marcel Hoogenboom, Particulier initiatief en overheid in historisch perspectief, in: Beleid en Maatschappij 38 (2011: 4), pp. 388-401, 391-392. 
developed a series of instruments to employ modes of supervision, control, or, at best, co-regulation. These ranged from formal recognition of semi-public or private organs with regulatory capacities, to financial support, to, as we have seen in the case of public health, the delegation of regulating self-regulatory practices to independent expert boards.

Within this kaleidoscopic reality, at least three significant historical conclusions can be drawn, which are interlinked to the current state of Dutch historiography.

First, as the seminal work of political scientist Arend Lijphart has highlighted, Dutch democracy has been characterised by the politics of accommodation from the early twentieth century onwards. ${ }^{47}$ Society was subdivided into distinct socio-political groups or pillars (i. e. Catholics, Orthodox Protestants, socialists, and liberals), whose elites, despite ideological differences, collaborated at the top levels of rule to sustain stability and define a shared common good. We have demonstrated that the arrangements of regulated self-regulation combining public and private actors were frameworks of consensual politics (and not only at top levels). Ideological differences were subordinated to a discourse in which the functional division of society was dominant. Regulated self-regulatory practices, therefore, can be said to have occurred in a setting that was relatively unaffected by the ideological frames of pillarization. This point links up with scholarship emphasizing the spaces between the pillars and research about the development of extra-parliamentary forms of democratic politics. ${ }^{48}$

A second observation entails the role of civil society - or organised interests in the institutional edifice of welfare arrangements. Whereas in many other European countries regulation was pursued by a pyramid of public agencies hierarchically connected from the local and the regional to the national level, the Dutch building blocks of self-regulatory practices were »run« by voluntary associations, mostly linked to interest groups in the socio-economic domain Whether in a collaborative arrangement with public bodies, in co-existence with

47 Cf. AREND LIJPHART, The politics of accommodation: pluralism and democracy in the Netherlands, Berkeley 1975.

48 Cf. IDO DE HAAN, Parlementaire democratie en maatschappelijke organisatie: de politieke context van de Sociaal-Economische Raad, in: BAS vAN BAvelet al. (eds.), SER 1950-2010: zestig jaar denkwerk voor draagvlak advies economie en samenleving, Amsterdam 2010, pp. 23-48; Nico RanderaAd, Het geplooide land; de pacificerende rol van de commissarissen des Konings en burgemeesters, in: J. C. H. Blom/J. TaLSmA (eds.), De verzuiling voorbij: godsdienst, stand en natie in de lange negentiende eeuw, Amsterdam 2000, pp. 134-153; Erik SchriJvers, Ongekozen bestuur. Opkomst en ondergang van het stelsel van adviescolleges en bedrijfsorganen (1945-1995), Ph. D. thesis, Utrecht University 2012. a public agency (as in the case of accident insurance) or not, trade unions, consumer organizations, employers' associations, and other interest groups relating to domains such as housing, health, or particular (regional) interests, became increasingly involved in the regulation of their sector. To be sure, the degree an level of involvement of voluntary associations in regulation differed significantly During the interwar years, national voluntary associations, which in most cases had many local branches, formed the pools of recruitment for advisory and selfregulatory organs. As such, these organs facilitated the emergence of selfregulatory practices within a tripartite setting, which capitalized on the ongoing participation of civil society in governance. ${ }^{49}$

Third, the organisation of welfare arrangements does not follow a strictly incremental or linear development towards the central state as the single fulcrum of regulatory activity. Surely, an increase in state-centred institutions and concomitant modes of self-regulation or co-regulation manifested itself from the 1920s onwards, but at the same time decentralised, corporatist arrangements continued or were created from scratch. Local forms of tripartism and publicprivate collaborations were typical features of Dutch welfare during the interwar period. ${ }^{50}$ By operationalizing the concept of regulated self-regulation, therefore, it is possible to come to a more balanced view of the emergence and growth of the Dutch welfare state.

Stefan Couperus and Nico Randeraad

49 F. van WAaRDen, Regulering en belangenorganisatie van ondernemers, in: F. L. van HolTHOON (ed.), De Nederlandse samenleving sinds 1815. Wording en samenhang, Assen 1985, pp. 227-260, 229; Remieg Aerts, Civil Society o Democracy? A Dutch Paradox, in: Bijdragen en mededelingen betreffende de geschiedenis der Nederlanden 125 (2010: 2/3), pp. 209-236; HeRTOGH, Geene wet (n. 37); W. P. Blockmans / L. A. van DeR VALK, Van particuliere naar openbare zorg, en terug? Sociale politiek in Nederland sinds 1880, Amsterdam 1992.

50 Cf. Harm KaAL, Het hoofd van de stad. Amsterdam en zijn burgemeester tijden het interbellum, Amsterdam 2008; Couperus, De machinerie (n. 13); Jelle GAEMERS, De rode wethouder. Willem Drees 1886-1988. De jaren 1886-1940, Amsterdam 2006 